This is an Accepted Manuscript of an article published by Taylor \& Francis in the AICCM Bulletin on 10 Oct 2019, available online: http://www.tandfonline.com/DOI:

10.1080/10344233.2019.1672942

Title: A Polar Explorer in Insanity's Archives: Transmitting the Story of Antarctic Wireless Operator Sidney Jeffryes

Author: Elizabeth Leane, School of Humanities / Institute for Marine and Antarctic Studies, University of Tasmania 


\begin{abstract}
:
This article recounts the author's journey through polar and asylum archives in order to tell the story of a forgotten Antarctic expeditioner. A radio operator for the Australasian Antarctic Expedition of 1911-14 (AAE) led by Douglas Mawson, Sidney Jeffryes was a pioneer of Antarctic telecommunications, making two-way wireless contact between the continent and the rest of the world for the first time in history. However, his mental illness during and after the expedition saw him institutionalised for the rest of his life and marginalised from Australian Antarctic exploration history. Telling Jeffryes' story challenges the way we remember Australian achievement in the Antarctic, but piecing this story together is far from straightforward. With published accounts often eliding his achievements or repeating centuryold misstatements, documents preserved in archives become key witnesses to his experience. The fragments of his story are found in letters, scribbled notes, wireless logbooks, registry entries and medical reports. Dispersed, messy, hard to find, faded, often illegible, and swamped by the masses of irrelevant documents surrounding them, these feel at times like the noisy signals that Jeffryes was required to decode in the Antarctic.

In attempting to transmit Jeffryes' story, this article also tells the story of deciphering his messages from the past, pointing to the value and the challenges of engaging with the material archive. For the conservator, the important message is that the material documents held in the archives, messy and frustrating as they were at times, enabled this retelling. Indeed, this messiness was an integral part of their message.
\end{abstract}

Keywords: archives, polar exploration, Australasian Antarctic Expedition, history of insanity, Antarctic heritage, Sidney Jeffryes

Word Count: approx. 8000, all inclusive (notes, bibliography, abstract, biography, acknowledgements) 


\section{A Polar Explorer in Insanity's Archives: Transmitting the Story of Antarctic Wireless Operator Sidney Jeffryes}

With increasing awareness of Antarctica's role in anthropogenic climate change in the last few decades, it has become common to compare the polar continent to an 'icy archive': a natural storehouse of information about past climate that humans can 'read' by drilling and analysing ice cores (e.g. Alley 2000, ch. 4). Less attention is given to the actual archives in which the records of human interaction with the Antarctic ice are stored. Long framed as a 'continent for science', Antarctica has rarely been considered a cultural and a historical place, and only in recent years has a group of humanities and social science scholars begun to challenge this framing (e.g. Roberts, van der Watt \& Howkins 2016). Moreover, archival work of the literal kind, typically taking place in a museum or public repository, lacks the glamour attached to more familiar Antarctic research undertaken on and in the polar ice, which still carries with it something of the intrepidness and heroism that characterised polar endeavour a century ago.

This article aims to give a sense of the author's encounter with the material traces that Antarctic explorers left behind, while simultaneously suggesting how, from these remnants, Australians might begin revisiting their Antarctic history. The particular focus is the Australasian Antarctic Expedition (AAE) of 1911-14, led by Douglas Mawson. This was the first Australian-led expedition to Antarctica, and the one which symbolically paved the way for the nation's claim on the continent (at forty-two percent of Antarctica, this is the largest of any national claim). For several years, the author has been part of an interdisciplinary research team, including polar psychologist Kimberly Norris and polar historian Ben Maddison, investigating and interpreting a little-known story of the AAE that challenges its dominant narrative of heroism, physical achievement and stoic masculinity. This is the story of AAE radio operator Sidney Jeffryes, who experienced a psychotic breakdown in midwinter 1913 that saw him committed to an asylum for the remainder of his life. <insert Fig. 1 near here $>$

Although Jeffryes achieved a world first by establishing two-way wireless radio communication between Antarctica and Australia, his severe mental illness during and after the expedition rendered his story untellable within the cultural ideologies of the time, which associated mental illness - particularly in men - with degeneracy and weakness (Coleborne 2015, p. 114). This is a story not of physical endurance, heroism and national pride, but of social tension, anxiety and national embarrassment. While other AAE narratives - particularly an epic solo sledging journey made by Mawson during the summer of 1912-13 - are 
incessantly repeated, Jeffryes' story was swept under the carpet on the expedition's return, and much of it has remained there ever since. For many years, his experience was rarely discussed in any detail in accounts of Antarctic exploration. Even now, when diaries and biographies of many of the AAE men have been published, Jeffryes' story remains marginal, related in narratives of the whole expedition (e.g. Riffenburgh 2011) or examinations of the psychological impact of polar conditions (e.g. Palinkas \& Suedfeld 2008, p. 153; Griffiths 2007; Haddelsey 2018, ch. 4), but never itself the central focus. Recently, the author and her colleague published accounts of Jeffryes' story for both academic and popular readerships, challenging some of the mythologies of early Australian Antarctic exploration (Leane, Maddison \& Norris 2019; Leane \& Norris 2018). Bringing Jeffryes' experiences into the foreground required burrowing into the depths of the archives, and it is this 'back story' that is offered here.

The archival component of this interdisciplinary project involved research in polar collections over several years. It also involved encounters with the archives of colonial asylums - fuller but often messier records and, to an Antarctic specialist, less familiar territory. Historian Catharine Coleborne (2010, n.pag), whose research focuses on Australasian colonial asylums of the kind to which Jeffryes was confined, describes the 'large, folio-sized clinical casebooks filled with patient admission notes and observations, admission registers, medical books, records of patient seclusion' and other documents of psychiatric institutions as 'insanity's archive'. The researcher's encounter with this archive, she reflects, is an emotional as well as an intellectual one:

Researchers themselves become ethnographers in the archive, with their decisions about methodological practice intimately bound up with their own positions on archival research praxis and their subjective choices. We too make choices, based on what we wish to find out, or on what moves us, both explicably and inexplicably, among the many records we locate.

When the historical subject of one's research is an Antarctic radio operator - someone whose role it was to interpret messages from a remote place - this encounter with the material archive takes on a particular resonance. Although cognisant of the enormous distance between Jeffryes' life and the author's own much more privileged existence, this article traces the interconnectedness between the respective roles of radio operator and archival researcher, both attempting to interpret partial and noisy signals from elsewhere. 


\section{Antarctic Midwinter, 1913: A Gothic Horror Story?}

While some people, conscious of posterity's potential interest in them, leave behind carefully curated versions of their lives in selected repositories, the stories of less prominent lives must be pieced together from documents scattered across numerous locations (where they are available at all). Sidney Jeffryes died childless in a maximum-security asylum and was buried nearby in an unmarked grave. ${ }^{1}$ His material traces, unsurprisingly, are dispersed and untidy, included incidentally in other collections relating to more prominent people or endeavours in which he was involved. They include the letters that he wrote to Mawson and to his own friends and family and the scrawled radio logs that he and others kept while members of the AAE - documents that are held in either the AAE records in the Mitchell Collection at the State Library of New South Wales or Mawson's own papers in the Australian Polar Collection at the South Australian Museum. They also include objects that remain in the freezing interior of the expedition hut at Cape Denison in Commonwealth Bay, which has itself been the focus of conservation efforts since the 1970s (Commonwealth of Australia 2013, p. 36).

There are, then, many material entry points to Jeffryes' story. For this author, as a literary studies scholar, a particularly suggestive beginning was provided by a photograph of a paperback novel that formed part of the expedition's library of books in 1913 and still remains in situ in Antarctica: Arthur Conan Doyle's The Hound of the Baskervilles. <insert Fig.2 near here $>.^{2}$ In the dead of a polar winter 1913, this novel provoked Jeffryes to an unexpected act of violence. ${ }^{3}$ Published about a decade prior to the expedition to great popular acclaim, Conan Doyle's most gothic Sherlock Holmes story centres on a series of attacks by a legendary demonic hound that take place in Dartmoor, a sparely populated, comparatively wild region in the south of England. The idea of Mawson's men reading this book in the long polar night is highly evocative. Like The Hound of the Baskervilles, the explorers' situation had all the ingredients of a horror story. To understand why, it is necessary to hold the events of midwinter 1913 in suspense - as a good detective novelist might - in order to outline some historical and geographical context.

The AAE left in late 1911, with the aim of scientific investigation and geographical exploration of the area of Antarctica south of Australia. In addition to his scientific and territorial aspirations (e.g. Argus 1911), Mawson hoped to achieve a technological first by establishing wireless radio contact between Antarctica and Australia. As well as its Main Base 
at Cape Denison in Adélie Land, the expedition included a second, smaller Antarctic base over two thousand kilometres to the west, and a wireless relay station comprising five men on the subantarctic Macquarie Island. The plan was for all expedition members to stay for just over a year, with a relief ship departing in late 1912 to take them home.

By early 1913, however, things were in disarray. The relief ship had come and gone, and there were still seven men left on the continent, all at the Main Base. Although Mawson had previously anticipated the possibility of a second year (Ayres 1999, p. 88; Riffenburgh 2011, p. 329), the situation that the seven men now found themselves in was quite unexpected. When the ship had arrived, a three-man sledging party led by Mawson had failed to return to base on time, and the vessel needed to depart again to pick up the men at the second Antarctic base before the weather closed in for another year. The decision was made to take most of the Main Base men home, leaving five volunteers to wait for the missing sledging party, even though this would mean an extra year in Antarctica. But the original radio operator, Walter Hannam, did not want to stay: he hadn't had a very successful year, with only a few messages being sent out and none received before one of the wireless masts blew down in mid-October 1912 (Mawson 1915, p. 224-5). The radio operator on the relief ship, Jeffryes, agreed to remain an unanticipated year in the south. ${ }^{4}$ Not long after the ship departed, the sledging party returned. But instead of three men it comprised only one Mawson - and he was close to death. The journey had been a disaster, with two men dying and the third, Mawson, forced to return to base alone with severely reduced equipment and rations - his famous epic journey.

Seven men, then, faced a whole year alone in the hut in 1913. The situation was challenging from any perspective. The six men staying on from 1912 were deeply shaken by the deaths of their two companions. Mawson struggled in the first few months after his return with both his physical and mental health. Not only had he been pushed to the limit of starvation and exhaustion, he had been leader of a journey on which both of his charges - the other men's beloved friends - had died. Although there is no direct evidence in the diaries relating to the rumours of cannibalism that later surrounded Mawson's remarkable survival, ${ }^{5}$ there are certainly dark hints of the resentment that some of the other men felt towards him (e.g. Madigan 2012, pp. 377, 391; and Jeffryes 1913b). All of this was exacerbated by a combination of claustrophobia, isolation, extreme weather - this was literally the windiest place on Earth - and, as the polar winter neared, darkness. In 1913, there was no one else on the entire continent. Their only communication with the outside world was the very new technology of the wireless that Jeffryes managed to get working early in the year. By 
midwinter 1913, however, the main wireless mast had blown down and all communication abruptly ceased. It was in this tedious yet remarkably charged environment that meteorologist Cecil Madigan, and expedition engineer and assistant wireless operator, Frank Bickerton, were reading Doyle's gothic crime novel.

On 6 July, Madigan reported in his diary (2012, pp. 397-8) that at dinner he had made a remark about The Hound of the Baskervilles to which Jeffryes had evidently taken exception. Sometime later in the evening, the meteorologist records, Jeffryes 'raged out, saying I was insinuating, and had better come into the next room'. Madigan 'answered heatedly', and Mawson had to step in; but the following day, Jeffryes challenged Madigan again - according to the latter's diary, the wireless man smacked him in the mouth, jumped on him, and hit him wildly. It was evident, Madigan reported, that the radio operator 'was out of his mind'. The expedition medical officer, Archie McLean (1913), concurred, diagnosing 'delusional insanity'. ${ }^{6}$

So began a very difficult few months for the seven men in the small Antarctic hut. Jeffryes continued to behave in a paranoid manner, believing the other men were insane and out to kill him. His violent threats continued and the firearms normally left lying around the hut had to be locked away. Jeffryes' hygiene deteriorated: he wouldn't wash, he began keeping his urine in bottles on a shelf and confessed (inaccurately it seems) that he was suffering from a venereal disease. ${ }^{7}$ None of these things were likely to endear him to his six companions living in close quarters. After a while the damaged wireless mast was fixed and, as the only experienced operator, Jeffryes continued operating the transmitter, until Mawson discovered him secretly sending out paranoid messages to Macquarie Island. In early October, he officially fired his wireless operator, with a dismissal letter that threatened exposure of his conduct if he ever made his story public (Mawson 1913). Jeffryes could not, of course, leave the workplace from which he had been dismissed. The men struggled on until late December, when the relief ship returned to take them to Adelaide in South Australia. They arrived home in late February as national heroes.

For Jeffryes, however, the horror story continued. Behaving erratically on the ship voyage to Australia, he took no part in the homecoming celebrations, but his leader deemed him 'normal' enough to board a train home to distant Toowoomba in Queensland (Sydney Morning Herald 1914, p. 21). He was found about a week later wandering starving in the Victorian bush, claiming that Mawson had hypnotised him - an incident reported by newspapers around the country. Mawson immediately went into recovery mode, distancing himself publicly from Jeffryes' employment, and claiming - with no obvious evidence - that 
the radio operator was mentally 'weak' from the time of his first arrival in Antarctica (Sydney Morning Herald 1914, p. 21). Meanwhile, Jeffryes was quickly committed to the nearby Ararat Hospital for the Insane. Initially shunted between several Victorian institutions, he was back in the Ararat asylum by late 1915 and remained there until his death in 1942 from a cerebral hemorrhage (Victoria, State Coroner's Office 1942).

By this time, he was in the asylum's J-Ward for the criminally insane, a wing of the institution located in a separate part of Ararat in a repurposed nineteenth-century gaol. Here, 'the most depraved and dangerous men in Victoria were ... housed in horrific conditions under the highest security' (Dax 2015, p. 168). Temperatures could be below freezing, and inmates were locked at night in stone cells open to the night air with only two 'suicide blankets' (stitched so that they could not be made into a noose) as undersheet and cover (Burgin 2009, pp. 38-9). The hut in Adélie Land must have seemed comfortable by comparison. Like the asylum itself (since renamed Arandale Mental Hospital), J-Ward is now a tourist attraction, offering daily tours as well as night-time ghost tours. Overshadowed by some of J-Ward's more notorious inmates, Jeffryes is nonetheless considered interesting enough to warrant a small interpretive sign in one of the cells. ${ }^{8}$ Touring the J-Ward buildings gives an insight - necessarily an oblique, mediated one - into his later life, but in order to understand why he spent so long in such a bleak place, it is necessary to explore the messy, widely distributed and hard-to-find papers that partially record his entry into and time within the asylum system. $<$ Insert Fig. 3a and b near here $>$

\section{Encountering the Polar and Asylum Archive}

Both institutionalised mental illness and polar exploration, for different reasons, produce prolific written records. In the former case, the apparatus of the legal and medical establishment ensured systematised documentation:

Rather than a paucity of sources to describe mental illness, there are patient records in abundance, as these were historically required by law to be kept and maintained ... it is something of an irony that the field of asylum studies can now tell us so much about groups of people who in their own time were hidden from view and away from the public gaze. (Coleborne 2010, n.pag) 
Coleborne (2010, n.pag) also notes, however, that researchers have become increasingly wary of claims for completeness or impartiality in these abundant archival records. In the case of asylums in Western nations, she observes that while most records from the nineteenth century onwards are in state-run collections, some have evaded official processes: 'In rare, but instructive, examples, the archival material may be found rotting in the basements or cupboards of disused institutions and rescued by researchers'. In the case of the Ararat Hospital for the Insane, where Jeffryes spent the second half of his life, it is tempting to imagine such a decaying storehouse. Frustratingly, the asylums in which Jeffryes spent very brief periods - Royal Park and Sunbury - seemed to have far more complete records than Ararat, where he lived for about twenty-five years. And as Coleborne points out, privacy laws mean that files from the twentieth century are often less accessible from those of the nineteenth. The case books in which Ararat asylum patients' files were recorded are all available, but this form of record-keeping for the Victorian asylums ceased in 1912, tantalisingly short of Jeffryes' committal. From this point the authorities moved to a looseleaf system in which files travelled with patients, and the trail of Jeffryes' file goes cold. It might be sitting, inaccessible, in a group of documents that also contains more recent files and hence is closed to the public; it might have been destroyed somewhere in the asylum's history or on its closure; or it might lie rotting in another location, inaccessible or unknown to the author. Other resources, including visitor books, correspondence files and administrative papers are available for Jeffryes' period, but these present a different challenge to the researcher. While the asylum records might be remarkably full, this fullness itself makes them difficult to navigate if the focus of the clue-hunt is an individual inmate.

In the case of early twentieth-century Antarctic exploration there was a different reason for ensuring that ample papers remained for posterity: no witnesses were available to vouch for one's achievements and return was not always assured. As guarantors of geographical discovery, logbooks, diaries and other records were paramount. Moreover, for most of those involved in early Antarctic exploration, the experience was an extremely novel and glamorous one, so diary-keeping was very common (e.g. Leane 2016, p. 37). For the same reasons, diaries and other papers from these endeavours are highly valued - in some cases, fetishised. Many are kept in institutional collections, painstakingly indexed and described; others are traded between private collectors and sold for large sums in auction houses. Those documents attached to particularly famous or tragic actors or episodes, such as Robert F. Scott's journals, are treated as national treasures and displayed in glass cabinets in 
libraries or museums. They represent the very opposite of the jumbled piles of papers that characterise the Ararat asylum archives.

The Antarctic archives - perhaps like those produced during periods of war or imprisonment - have a particularly evocative materiality. Often written in difficult conditions, diaries of polar expeditioners bear the marks of their circumstances of production in exotic ways: they might be stained by blubber-smoke when their author was forced to live under a boat or in an ice-cave; missing pages that have been torn out to save weight on a sledging journey; or recovered from a dead body. For polar enthusiasts, these holograph manuscripts offer unique a material connection to the place in which and people by whom they were written. For researchers, they contain information that published and digital versions, no matter how carefully edited or reproduced, cannot fully capture.

While digital copies, facsimiles and transcriptions are indispensable for protecting delicate original artefacts, remote access and efficiency of use, the author's experiences with archives relating to the AAE confirmed the importance of encountering historical documents in their original form. Tears or marks on paper, the pressure of a pen, the size and thickness of a diary, all bear traces of the material circumstances and emotional state in which the document was produced that provide context for the interpretation of the information it contains. Mawson's notes about Jeffryes and other expeditioners, for example, come in a variety of forms - little slips of paper that have been cut out of larger leaves, scrawls on the back of scientific tables, annotations on someone else's notes - that not only speak to finite resources of a remote base but also the daily pressures under which the expedition leader operated. <insert Fig. 4 near here> One revealing document is the monthly in-house 'newspaper', 'The Adelie Blizzard', begun in 1912 but largely produced in 1913, to provide the AAE men with occupation during the dark winter and (it was hoped) help publicise the expedition on its return. Jeffryes contributed an account of his journey to Antarctica, but the essay (which had two instalments) was physically cut out from the original copy of the newspaper held in the Australian Polar Collection (Leane 2005, pp. 16, 19). Why, by whom and when was Jeffyres' contribution excised in this way? While the answers to such questions are often speculative and subjective, archival documents certainly offer clues that exceed the information found in the written words they contain.

\section{Archival Interpretation: Solving a Mystery or Detecting Faint Signals?}


Jeffryes did not, it seems, keep a diary, but he did write a number of letters from Antarctica and Ararat. The author's transcripts of these, as well as the other expeditioners' diaries, enabled psychologist Kim Norris to confirm what earlier commentators (e.g. Roberts 2013, p. 271) already suspected: that Jeffryes suffered from symptoms consistent with what we now call schizophrenia, likely triggered by stress (Leane, Maddison \& Norris 2019). This retrospective diagnosis gives the task of uncovering the event that set off his illness in Antarctica heightened interest. For a literary critic, the incident that happened in early July, when Conan Doyle's novel apparently sparked Jeffryes' early violent episode is particularly intriguing. What might the comment have been that enraged him so? The copy of the paperback novel itself might potentially contain clues: notes written in the margin or passages underlined. However, in accordance with the Management Plan of the Mawson's Huts Historic Site (Commonwealth of Australia 2013, p. 73), The Hound of the Baskervilles, along with other AAE artefacts left behind by the AAE men, remains in situ in the hut at Cape Denison - a place that has become particularly difficult to reach in the last few years, since a large iceberg lodged nearby has led to a build-up of sea ice around the site. But although the material object is elusive, the novel's textual content provides possible leads.

While the narrative of The Hound of the Baskervilles might ostensibly seem remote from Antarctic concerns, a careful read reveals striking similarities between its setting and action and the events at Cape Denison. The high, flat moor on which the Baskerville ancestral home is located is an isolated and dangerous place, edging onto the great and dreaded (fictional) Grimpen Mire, where treacherous patches of bog await the unsuspecting - an 'uncanny place altogether' (Doyle 2003, p. 69). The Antarctic plateau is also isolated, high, flat and criss-crossed by unseen dangers - not patches of mire but crevasses, like the one into which one of Mawson's sledging companions disappeared without a sound, never to be seen again. And then there are the numerous references to madness in Conan Doyle's novel. A subplot involves an escaped inmate of Dartmoor's famous prison, a murderer who has evaded the gallows only because he was deemed insane but ends up victim to the dreaded hound. In one letter that Jeffryes apparently wrote not long after the fight with Madigan, he claimed that he was being 'hounded' by the expedition doctor, Archie McLean, and the other men, who believed him insane. ${ }^{9}$ But Mawson $(1988$, p. 169) wrote in his diary that Jeffryes considered the title of the novel to be a 'reference to himself'. Jeffryes was, it seems, both hound and hounded, mad escapee and trapped animal.

Where Holmes' mystery took him to Dartmoor, the trail of Jeffryes' archival record led to no such romantic locale, but rather to the Public Record Office Victoria (PROV), where 
both the filing system and the contents of the asylum archives posed challenges for a researcher new to these records. Neither was made easier by the unusual spelling of Jeffryes' name, which in historical source material is rendered variously as 'Jeffries', 'Jeffreys', 'Jefferys', 'Jeffereys' and even, surprisingly, 'Jeffryies'; by his being christened 'Sydney' with a ' $y$ ' but using an ' $i$ ' most of his adult life, so that both appear in the records; and by a typographical error that seemingly occurred during the expedition, in which his middle initial ' $\mathrm{H}$ ' for Harry was mistranscribed as ' $\mathrm{N}$ ' - something perpetuated in many related documents. A quick calculation confirms that these alternatives create twenty-four possible name combinations for Jeffryes. At times, the archives felt a little like Grimpen Mire, a huge expanse of material covered with, to use Dr Watson's words, 'little ... patches everywhere into which one may sink and with no guide to point the track' (Doyle 2003, p. 73).

Persistent searching, however, produced a number of basic official documents: hospital registers and transfers; a coroner's report; and the Ararat asylum's visitors' book. A side trip to the Ballarat branch of PROV revealed that, according to court records, Jeffryes had been consigned to a 'lutanic' asylum (Petty Sessions Register 1858-1967) - it seems the people determining his future couldn't even spell the facility to which he was committed. Other documents remained elusive - in particular, Jeffryes' patient case notes. As the research continued, with The Hound of the Baskervilles always in the background, the author began to imagine herself as a detective forensically piecing Jeffryes' story back together. Just as Holmes solves the secret of the hound and allows the heir to the Baskerville estate to assume his rightful place, so, this fantasy went, Jeffryes would be rescued from oblivion by the author's deciphering of the mysteries of the archives.

In actuality, of course, the plodding Watson proved a better model than the brilliant Holmes. The asylum registers were surprisingly unenlightening. The Sunbury admissions register entry from mid-1915 has Jeffryes' profession as 'labourer' and only a question mark under 'Supposed Cause of Insanity' (Register of Patients, 1877-1920). The institutional system levelled out the hierarchies of social and professional status that characterised the outside world: a year after his return from Antarctica, all traces of Jeffryes' identity as a polar explorer and radio operator had vanished. When the Ararat case notes drew a blank, the asylum's general correspondence files were the next target. Receiving the item, the author wondered if anyone else had ever looked at these documents since they were first filed. 'Filed' is generous, as apart from being bundled into years, these papers were an arbitrary assemblage, in which an application for a gardening job might rub shoulders with a note about kitchen supplies. $<$ insert Fig 5 near here $>$ While this lack of organisation was in some 
ways an obstacle to research - the chances of finding something related to Jeffryes seemed so slim and the task of sorting through these miscellaneous documents so daunting that this item could easily have been put aside - it was also illuminating. Hidden in amongst the mundane remnants of the day-to-day business of a large institution were various patient notes, revealing the degree to which clinical and administrative information were entangled in everyday exchanges of the institution. One of these patient-related documents was a carbon copy of a long 1920 report on Jeffryes' health since he arrived in the asylum (Shaw 1920). This confirmed that Jeffryes' condition - by now classified as 'Chronic Delusional Insanity, Systematised' - had only worsened since his institutionalisation, although by this time the Freemasons, not his Antarctic companions, were the subject of his paranoia. References to violent episodes, including one that occurred in Sunbury asylum, prior to his transfer back to Ararat, went some way to explaining why he ended up in J-Ward, although not exactly when.

Unlike the systematic, deductive techniques made famous by Holmes, serendipity often proved the best route to information in the Ararat quarter of insanity's archives. A mistake with the call number when ordering up an item led to the discovery of the outward correspondence books of the asylum where carbon copies of letters sent by the medical staff were collated. These are huge tomes with many hundreds of pages per year. Opening one volume at random, the author lucked on the name 'Jeffreys'. This was one of what turned out to be many dozens of letters from medical staff addressed to administrators or to Jeffryes' family - the sisters and mother who kept up their enquiries for decades, despite never, it seems, receiving a reply from him. Many of these letters were so faded as to be near-illegible. A careful search through them nonetheless produced, inter alia, small nuggets of insight. Most striking was a letter written by the medical superintendent only a few months after Jeffryes' initial admission - a time, it seems, when his Antarctic experience was still within institutional memory. He was doing well, the medical superintendent wrote to the Inspector General for the Insane, and had been put to work in the asylum's administration area:

he is engaged at Clerical work in the Office; this he does well, but at times becomes pre-occupied and assumes an attitude as if receiving wireless messages....

There is no doubt that the Polar experience had made a very marked, possibly indelible - mental impression, owing to hardship but chiefly to worry in connection with the receiving, or failure to receive, messages so faint as to be at times indecipherable. (Philpott 1914) 
This letter confirmed what historian Ben Maddison had already suspected from expedition diary evidence: that Jeffryes' problems were closely connected to the unrelenting effect of workplace pressures (Leane, Maddison \& Norris 2019). Mawson had trumpeted the wireless as a key component of the expedition, and with its first year being, in his words, 'a public misfortune' in this regard, it was up to Jeffryes to make good on this claim so that the 'honours' could be 'retrieved' (Mawson 1915, p. 153). Just as importantly, the wireless was the only way the men could contact their loved ones who were waiting an extra year for their return. Mawson, keen to prioritise expedition news, policed the airwaves in a manner that at least one of his men (Madigan 2012, pp. 364, 387) found too controlling and even selfaggrandising. Tensions ran high around whose messages were sent and when. With radio signals competing with the noise of the wind, the dogs, and interference from atmospheric phenomena such as the aurora australis and St Elmo's Fire, listening for radio signals was 'very tedious and nerve-racking work' (Mawson 1915, p. 136). In addition, Jeffryes had to work late into the night, when radio waves could travel further distances, and Mawson was unrelenting in his insistence on a strong work ethic. ${ }^{10}$ It was perhaps no coincidence that the timing of Jeffryes' first episode occurred not long after the collapse of the main wireless mast (Leane, Maddison \& Norris 2019), which put an end to his regular work and posed the challenge of reassembling the equipment.

Among the papers preserved in the Australian Polar Collection are the logbooks of all the wireless messages sent from and received by both the Main Base and the Macquarie Island relay station. In light of the medical superintendent's comments they seemed newly important. Reading and comparing their voluminous, messy pages was both daunting and revealing. Jeffryes' handwriting becomes - literally - loopier and loopier. <insert Fig. 6 near here $>$ Mawson annotates Jeffryes' notes, his additions increasing in urgency as he realises that his radioman has been sending out secret, paranoid messages, including one saying that he and Mawson are leaving the hut because the other five men are 'not too well' (Adelie Land Base 1913). Comparing the log books from Adélie Land and Macquarie Island, however, it is clear that only a single, harmless, secret message asking urgently about Jeffryes' mother's health ever escaped Antarctica. The men stationed on Macquarie Island remained oblivious to the drama unfolding a thousand miles to their south. Nonetheless it is perhaps here, in the wireless logbooks, that both the cause and outcome of Jeffryes' illness are most legibly inscribed. 
A focus on Jeffryes' professional position in the expedition and the stresses of his work environment provides a different perspective on what drove him, quite literally, insane. Jeffryes' story, from this angle, is not a case study in 'midwinter madness', a gothic tale of one man's inability to deal with the isolation and darkness. Rather, it is a story of group dynamics, interpersonal tensions and work management. If it were to happen today, terms such as 'duty of care', 'occupational health and safety' and perhaps even 'workplace bullying' might be applied. This version of Jeffryes' story is one that contests the dominant narrative of Australian Antarctic exploration - that asks us to value this activity not (or not only) for its tales of high adventure and heroic endurance, but also for its complex, fascinating and sometimes disturbing mix of personalities, motives and actions, all inflected by cultural assumptions around work, masculinity and the imperial project. This is the story that the archival material described here eventually enabled the author and her colleagues to tell (Leane, Maddison \& Norris 2019).

And just as the desire to read Jeffryes' story through the lens of gothic horror is misplaced, so too is figuring of the archives as Grimpen Mire, and the researcher as Sherlock Holmes, or at least Dr Watson, picking her way carefully through them and collecting the evidence that would allow her to bring the case to a close and give a final denouement. Instead, the archives are perhaps better imagined as white noise, a series of undifferentiated transmissions from the past. Faded, often illegible, and swamped by the masses of irrelevant material surrounding them, archival documents feel at times like the signals that Jeffryes was required to decode in the Antarctic. Just as Jeffryes had been, as one newspaper of the time put it, 'assailed nightly by wireless signals from far and wide, so much that it [wa]s usually difficult to pick out the particular ones' (The Australasian 12 April 1913), so the researcher into his experience has to make out, from among the chaotic signals of the past, 'messages so faint as to be at times indecipherable' (Philpott 1914).

\section{Conclusion}

Where Mawson's epic sledging journey is a story of individual survival against the odds, Jeffryes' is one of communication and its obstacles - of the pleasures and pitfalls of receiving and transmitting distant messages. Having strained to hear faint signals from the past, the author could only relay a version of what she has deciphered - one subject to inevitable distortion, attenuation and interference. The condition and location of archival documents at times made the researcher's task of interpreting already-weak signals even more testing and 
the results more tenuous. No doubt signals were missed or misinterpreted, and future researchers may decode them anew to tell different stories.

For the conservator, the important message is that the material documents held in the archives (as well as artefacts excavated as part of conservation efforts in Antarctica), messy and frustrating as they were at times, enabled this retelling. Indeed, this messiness was an integral part of their message. While their dispersed, disordered and deteriorated condition formed an obstacle to research, it simultaneously spoke of Jeffryes' own lived experience, as someone irrevocably damaged by his part in exploration of the far south, lost in the medical system and largely forgotten by posterity. Together the polar and asylum archives enabled Jeffryes' story to be told anew, revealing that early Australian Antarctic exploration was not simply a series of heroic exploratory and scientific endeavours, but could at times be a chaotic and disturbing enterprise.

Funding: This work was supported by the Australian Research Council under FT120100402; and the University of Tasmania under L0024246.

Acknowledgements: This research is an offshoot of the author's collaboration with $\mathrm{Dr}$ Kimberly Norris and Dr Ben Maddison and has benefitted from discussions with them. The author is also indebted to the Mawson's Huts Foundation, members of the Friends of J-Ward, and the staff of the Australian Polar Collection at the South Australian Museum for discussions about Jeffryes, although they have no responsibility for the ideas expressed here. Comments from two anonymous reviewers were also very helpful.

\section{Author Biography}

Elizabeth Leane is Professor of English at the University of Tasmania, where she holds an Australian Research Council Future Fellowship split between the School of Humanities and the Institute for Marine and Antarctic Studies. She has bachelor's degrees in physics and literary studies, and undertook her doctorate at the University of Oxford. Her books include South Pole: Nature and Culture (2016), Antarctica in Fiction (2012) and Reading Popular Physics (2007). She is Arts and Culture editor of The Polar Journal. Elizabeth.leane@utas.edu.au

\section{References}


Adelie Land Base: wireless messages received and sent 1913, South Australian Museum, Australian Polar Collection, Adelaide, 28AAA/10.

Alley, R 2000, The Two-Mile Time Machine: Ice Cores, Abrupt Climate Change, and Our Future, Princeton University Press, Princeton, NJ.

The Argus 1911, 'Exploring Antarctica. Mawson Expedition. Leader's Intentions', 24 July 1911, p. 6.

Australian Antarctic Division 2014, 'Sidney Jeffryes', Home of the blizzard: the Australasian Antarctic Expedition, Australian Government Department of Environment and Energy, viewed 19 December 2018, <http://mawsonshuts.antarctica.gov.au/cape-denison/thepeople/sidney-jeffryes $>$.

The Australasian 1913, 'Icebound Explorers. Messages from Dr Mawson', 12 April 1913, p. 35.

Ayres, P 1999, Mawson: A Life, Melbourne University Press, Melbourne.

Burgin, RG 2009, The J Ward story, R Graeme Burgin, n.pag.

Coleborne, C 2010, 'Reading insanity’s archive: reflections from four archival sites', Provenance: The Journal of the Public Record Office Victoria, no. 9.

Coleborne, C 2015, Insanity, identity and empire: immigrants and institutional confinement in Australia and New Zealand, 1873-1910, Manchester UP, Manchester.

Commonwealth of Australia, Australian Antarctic Division 2013, Mawson's huts historic site management plan 2013-2018, Australian Antarctic Division, Kingston, Tasmania.

Dax, EM 2015, 'Ararat's J Ward: a history cast in stone', World Cultural Psychiatric Research Review, vol. 10, no. 3/4, pp. 168-74. 
Doyle, AC 2003, The hound of the Baskervilles: another adventure of Sherlock Holmes, ed. C Grayling, Penguin, London.

Griffiths, T 2007, 'Madcap icecaps', Age, 12 May 2007, viewed 16 April 2019, $<$ https://www.theage.com.au/technology/madcap-icecaps-20070512-ge4v46.html>.

Haddelsey, S 2018, Icy graves: exploration and death in the Antarctic, The History Press, Stroud, Gloucestershire.

Jeffryes, S 1913a, Letter to Mrs Fox, 13 July 1913, South Australian Museum, Australian Polar Collection, 177AAE.

Jeffryes, S 1913b, Letter to Douglas Mawson, 30 July 1913, South Australian Museum, Australian Polar Collection, 177AAE.

Leane, E 2005, 'The Adelie Blizzard: the Australasian Antarctic Expedition's neglected newspaper', Polar Record, no. 41, n.pag.

Leane, E 2016, 'Antarctic diaries and heroic reputations: changing the subject', in Roberts, P, van der Watt, L and Howkins, A (eds), Antarctica and the humanities, Palgrave Macmillan, London, pp. 27-51.

Leane, E, Maddison, B, and Norris, K 2019, 'Beyond the heroic stereotype: Sidney Jeffryes and the mythologisation of Australian Antarctic history', Australian Humanities Review, no. 63 , n.pag.

Leane, E, and Norris, K 2018, 'Remembering Sidney Jeffryes and the darker side of our tales of Antarctic heroism', The Conversation 16 October 2018, n.pag,

$<$ https://theconversation.com/remembering-sidney-jeffryes-and-the-darker-side-of-our-talesof-antarctic-heroism-105034>.

Madigan, C 2012, Madigan's account: the Mawson expedition: the Antarctic diaries of C.T. Madigan 1911-14, ed. JW Madigan, Wellington Bridge Press, Hobart. 
Marks, K 2013, 'Cannibalism and calculation: a dark story from the white continent', Independent, 3 November 2013, viewed 16 April 2018,

$<$ https://www.independent.co.uk/news/world/australasia/cannibalism-and-calculation-a-darkstory-from-the-white-continent-8919837.html>.

Mawson, D 1911a, Letter to Walter Hamman, 19 October 1911, State Library of New South Wales, Mitchell Library, MSS 171/14.

Mawson, D 1911b, Letter to Walter Hamman, 27 October 1911, State Library of New South Wales, Mitchell Library, MSS 171/14.

Mawson, D 1913, Letter of dismissal to Sidney Jeffryes, 4 October 1913, Australian Polar Collection, South Australian Museum, 177AAE.

Mawson, D 1915, The home of the blizzard: being the story of the Australasian Antarctic Expedition, vol. 2, Heinemann, London.

Mawson, D 1988, Mawson's Antarctic diaries, vol. 2, ed. F \& E Jacka, Allen \& Unwin, Crows Nest, NSW.

McLean, AL 1913, 'Diaries 2 December 1911 - 26 February 1914', State Library of New South Wales, Mitchell Library, MSS 382/1.

New York Evening Globe 1913, 'Mawson Tells of Horrors of the Antarctic: Companions Die, and Explorer After Two Days Decides Not to Eat One of Them-Wonderful Escapes', 13 January 1915, press cutting in scrapbook 257.1.3, South Australian Museum, Australian Polar Collection.

Palinkas, LA \& Suedfeld, P 2008, 'Psychological effects of polar expeditions', The Lancet, no. 371 , pp. $153-63$.

Petty Sessions Register (Stawell) 1858-1967, Public Records Office of Victoria, VPRS 4914/P0000, Unit 33. 
Philpott, AJW 1914, Letter to Dr Jones, 1 June 1914, Administration Outward Letter Books 1868-1939, Public Records Office of Victoria, VPRS 18192/P0001, Unit 34, p. 527.

Register of Patients, Sunbury, 1877-1920, Public Records Office of Victoria, VPRS 8236/P1, Unit 4.

Riffenburgh, B 2011, Aurora: Douglas Mawson and the Australasian Antarctic Expedition 1911-14, Erskine Press, Eccles, Norwich.

Roberts, D 2013, Alone on the Ice: the greatest survival story in the history of exploration, WW Norton, New York \& London.

Roberts, P, van der Watt, L, \& Howkins, A 2016, Antarctica and the humanities, Palgrave Macmillan, London.

Shaw, Patrick (Medical Superintendent) 1920, 'Report with regard to a patient Sidney Jeffryes', 27 February 1920, attached to letter from the Inspector General of the Insane to Littleton E. Groom, 1 March 1920, Public Records Office of Victoria, VPRS 7525/1.

Sydney Morning Herald 1914, 'Lonely Antarctic', 14 March 1914, p. 21.

Victoria, State Coroner's Office 1942, Proceedings of Inquest, Sydney Jeffreys, Public Records Office of Victoria, VPRS 24/P/1455/1942/1427.

\section{Figure Captions}

Fig. 1. Sidney Jeffryes, with wireless mast behind him. This photograph is the only known image of Jeffryes. Image source: John King Davis, Courtesy of the State Library Victoria.

Fig. 2. The copy of The Hound of the Baskervilles read by Mawson's men, as uncovered by conservators of the Mawson's Huts Historic Site. The novel remains in the hut in Antarctica. Image source: Colin Monteath. Used with permission.

Fig. 3a. The J-Ward buildings in 2018. Image source: author. 
b. The J-Ward cell in which a brief account of Jeffryes' life is featured. Image source: author.

Fig. 4. Mawson's note on a wireless message recorded by Jeffryes, one of a miscellaneous group of messages held together with a pin, 'Adelie Land Base: Wireless Messages Received and Sent: 1913', Australian Polar Collection, South Australian Museum, 28AAE/10. Image source: author. Used with permission.

Fig. 5. A box of Ararat asylum ‘Correspondence Files 1919 - ?1935’, Public Records Office of Victoria, VPRS 7525. Image source: author.

Fig. 6. A page from the radio log book kept by Jeffryes and annotated by Mawson, 'Adelie Land Base: Wireless Logs’ 1913, Australian Polar Collection, South Australian Museum, 35AAE/1. Image source: author. Used with permission.

\footnotetext{
${ }^{1}$ This situation has since been rectified: while the author was searching for Jeffryes' archival traces, someone else was on the track of his physical remains. Terry Schulz, a former psychiatric nurse in J-Ward, heard during a tourist trip to Cape Denison that one of Mawson's expeditioners had ended up in his erstwhile workplace. On his return, Schulz managed to locate Jeffryes' grave in the public cemetery at Ararat, marked only by a numbered peg. He informed the Mawson's Huts Foundation, who organised a large bronze plaque to recognise Jeffryes' achievements, which was laid in a ceremony on 16 October 2018, on the seventy-sixth anniversary of his death. ${ }^{2}$ The photograph included here was sent to the author by photographer, writer, mountaineer and bookseller Colin Monteath; the curator of the Australian Polar Collection, Mark Pharaoh, had earlier shown her a similar image. Both were aware of her interest in Jeffryes. Such generous acts of collegiality often provide the impetus for an unexpected research journey.

${ }^{3}$ While a novel might seem an unusual object from which to begin a story about mental illness, books and reading were actually an ongoing source of tension in the AAE. They provided one of the few ways of alleviating boredom and for this reason were highly prized.

${ }^{4}$ His readiness to do so is not particularly surprising. In 1911, Jeffryes had been interviewed by Mawson for the role of radio operator at one of the expedition bases. He was considered suitable but others had already been recruited, so he was effectively wait-listed (Mawson 1911a, 1911b). In early 1913, he unexpectedly had the chance to fulfil his ambition.

${ }^{5}$ These rumours seem to have been first circulated in US tabloid newspapers after the expedition's return (e.g. New York Evening Globe 1915). A century later, the issue was still a live one: when historian David Day in 2013 again raised the possibility that Mawson (among other things) ate his dead companion, it generated media headlines in 2013 (e.g. Marks 2013).

${ }^{6}$ Compared to the other AAE 1913 diarists, McLean is surprisingly reticent about Jeffryes. One would expect him, as the base physician, to have kept detailed notes, suggesting that a separate AAE 'patient file' may exist or at least have existed. The author has found no trace of it thus far.

${ }^{7}$ These details of Jeffryes' behaviour can be found inter alia in the entries for July 1913 in Mawson 1988 and Madigan 2012.

${ }^{8}$ A more substantial display devoted to Jeffryes is currently in development.

${ }^{9}$ The quotation in which Jeffryes refers to himself as 'hounded' is reproduced on an Australian Government (Australian Antarctic Division 2014) website about the AAE, but finding the original document was itself something of a detective story. The website attributes the quotation to a 13 July 1913 letter from Jeffryes to a 'Mrs Fox'. However, a letter of the same date and addressee held in the Australian Polar Collection includes no such passage (Jeffryes 1913a), and no other letter of this date is evident in the AAE-related papers held there or
} 
in the State Library of New South Wales. Eventually, an enquiry to the latter led to a letter enclosed in a copy of another book in the expedition's library, Electricity in the Service of Man, which (unlike The Hound of the

Baskervilles) evidently returned to Australia. Perhaps Jeffryes began this letter, thought the better of it, enclosed it in the book and later began the second, complete letter.

${ }^{10}$ While nights were long in Antarctica through the winter months, signals had to travel to and from further north, where nights were shorter. Jeffryes would often be expected to stay up until after midnight, putting him out of sync with his companions. 